\title{
Heavy metal contamination in the vicinity of an industrial area near Bucharest
}

\author{
Teodor Velea • Liliana Gherghe • Vasile Predica • \\ Rolf Krebs
}

Received: 25 April 2008 / Accepted: 29 September 2008 / Published online: 20 December 2008

(C) Springer-Verlag 2008

\begin{abstract}
Background, aim, and scope Heavy metals such as lead are well known to cause harmful health effects. Especially children are particularly susceptible to increased levels of lead in their blood. It is also a fact that lead concentration is increasing in the environment due to increased anthropogenic activity. The risk of heavy metal contamination is pronounced in the environment adjacent to large industrial complexes. In a combined case study, the environmental pollution by heavy metals was related to children's health in the vicinity of an industrial area located $4 \mathrm{~km}$ south-east from Bucharest about $2 \mathrm{~km}$ east from the nearest townPantelimon. This site includes companies processing different, nonferrous solid wastes for recovery of heavy metals and producing different nonferrous alloys and lead batteries. In this paper, mainly the results of environmental sampling and analyses are summarized.

Materials and methods Water, soil, and atmospheric deposition samples were collected from different locations within $3 \mathrm{~km}$ from the industrial area. For comparison, samples were also taken from Bucharest. Water samples
\end{abstract}

\section{ESPR Special Issue - ESTROM}

Responsible editor: Walter Giger

T. Velea $(\bowtie) \cdot$ L. Gherghe $\cdot$ V. Predica

Laboratory of Environment Protection and Eco-technologies,

National Research and Development Institute

for Nonferrous and Rare Metals,

102 Biruintei Boulevard,

Pantelimon, Romania

e-mail: tvelea@imnr.ro

R. Krebs

Institute of Natural Resources Sciences,

Zurich University of Applied Sciences,

Schloss, CH-8820 Wädenswil, Switzerland were filtered $(<0.45 \mu \mathrm{m})$, extracted by salpetric acid, and quantified by ICP-OES and ICP-MS. Soil samples were dried, sieved $(<2 \mathrm{~mm})$, extracted by aqua regia and analyzed by AAS. In order to quantify the atmospheric deposition, three kinds of permanently open collecting pots were used on nine different sites between August and November 2006.

Results At most sampling locations, the heavy metal concentrations in soil decrease with increasing distance to the presumably major source of pollution. Highest heavy metal concentrations were found in $10-20 \mathrm{~cm}$ soil depths. There were also decreasing heavy metal concentrations for atmospheric deposition with increasing distance to the industrial site. In surface and groundwater samples, traces of zinc, copper and lead were detected.

Discussion The heavy metal concentrations in soil were increased in the study area, mostly under legal action limits in low-concern areas (e.g., 1,000 mg Pb/kg dry soil), but often above action limits for high-concern areas $(100 \mathrm{mg} \mathrm{Pb} / \mathrm{kg}$ dry soil) such as populated areas. The soluble lead concentrations in water samples indicate a need for monitoring and assessing water quality in more detail. The results for atmospheric deposition showed increased dust precipitation and heavy metal loads in the study area compared to Bucharest. However, based on mass flow balance calculations, the actual atmospheric deposition of heavy metals must be much lower than it was in the past decades.

Conclusions It was shown that highest lead values in water, soil and atmospheric deposition are rather to be found near the investigated industrial site than at the control sites in Bucharest. Our results correspond very well with results that show that children from Pantelimon have significantly increased lead concentrations in their blood compared to children in Bucharest. The increased lead contamination around the investigated industrial area is likely to have 
caused the increased exposure for children living in Pantelimon.

Recommendations and perspectives In high-concern areas, such as found in populated areas, further measures have to be taken to avoid health risks for people living in these areas. The measures already taken to reduce emissions from the industrial site will help to avoid further increases in heavy metal concentrations. In areas with exceeded action limits, measures have to be taken as required by law. Detailed risk assessments could help to take necessary actions to protect public health in this area. The public should be informed about the potential hazards of eating plants grown in that area. Educational programs for schools, informing children about the contamination, should lead to a better understanding of environmental problems and a more sustainable behavior in the future.

Keywords Atmospheric deposition · Children .

Contamination $\cdot$ Heavy metals $\cdot$ Lead $\cdot$ Public health $\cdot$ Soil

\section{Background, aim, and scope}

Heavy metals and especially lead are well known to cause harmful health effects. Children are particularly susceptible to increased levels of lead in their blood, because their enteral lead absorption is higher than that of adults $(10 \%$ vs. $50 \%$ ) and children relative to adults eat, drink, and inhale more on a body-weight basis. Furthermore, their behavioral characteristics (outdoor activity, hand-to-mouth-activity) place them at a higher risk to exposure and the developing brain is more vulnerable to the effects of many chemicals than the adult brain. These considerations have led to defining a lower blood-lead-concentration as being critical for neurobehavioral effects in children than for adults, namely $100 \mathrm{vs.} 400 \mu \mathrm{g} / \mathrm{l}$. There is evidence today that, even at blood-lead levels below $100 \mu \mathrm{g} / \mathrm{l}$, neurobehavioral effects of lead are likely to occur in children, although such effects are typically minor and of doubtful clinical relevance (Nicolescu et al. 2008).

Diffuse pollution of the environment by heavy metals is a major environmental problem world-wide. An important input pathway is the atmospheric deposition of industrial, traffic, and household emissions (Schulin et al. 2007). In Romania, gasoline was leaded until 2008 and traffic was therefore certainly an important source for lead. The risk of heavy metal contamination is pronounced in the environment adjacent to large industrial complexes. Many cases of particularly severe metal pollution by atmospheric deposition have been reported from areas surrounding nonferrous metal smelters in many countries (Steinnes et al. 2000; Kabala and Singh 2001; McMartin et al. 2002; Martley et al. 2004). Typically, these studies found highly elevated concentrations of the emitted metals in the topsoils adjacent to smelting facilities. Often, soil metal concentrations were found to decrease with increasing distance from the smelter (Schulin et al. 2007). However, considerable variability can result, e.g., from disturbances in the transfer and deposition processes, but also from the superposition of different inputs.

In this case study, we investigated an industrial site near Bucharest, which is thought to be the major source of heavy metal deposition in the surroundings. The site stands as an example for many similar industrial activities in Romania. The study site includes two plants recovering heavy metals, such as lead, from solid wastes. In this combined study, the environmental pollution was related to children's health in the vicinity of this area. In this paper, we will present the assessment of soil, air and water contamination and discuss possible correlations with results obtained by analyzing the blood of children living in Pantelimon and Bucharest (Velea et al. 2008; Nicolescu et al. 2008).

\section{Materials and methods}

\subsection{Sampling locations}

The presumably major source of pollution is an industrial area which is located $4 \mathrm{~km}$ south-east from Bucharest about $2 \mathrm{~km}$ east from the nearest village (Pantelimon). Samples of soil, atmospheric depositions and water were taken between September 2005 and May 2007 at different locations around this industrial area. For comparison, samples were also collected in Bucharest from places near the living area of the children participating in the combined medical study (Velea et al. 2008).

The soil samples were collected along transects at 200, $500,1,000$ and 2,000 $\mathrm{m}$ distance from the industrial area mainly along the main wind direction from west to east at different depths: $0-5 \mathrm{~cm}, 5-10 \mathrm{~cm}$, and $10-20 \mathrm{~cm}$. In addition, samples were taken at depths of $20-50 \mathrm{~cm}$ and $50-100 \mathrm{~cm}$ at points of 200,500 , and $3,000 \mathrm{~m}$ distance to characterize the soil profile. Soil samples from Pantelimon were collected from 22 sites randomly distributed over the whole town at $0-10 \mathrm{~cm}$ depth. In Bucharest, samples were collected from four different control sites close to the area where children participating in the medical study were living.

To assess atmospheric deposition, samples were collected $50 \mathrm{~m}, 500 \mathrm{~m}$ and $1,500 \mathrm{~m}$ from the industrial area along the main wind direction from west to east.

The sites for water samples are shown in Fig. 1: lakes (samples 1, 2, 5), a fountain from Pantelimon (sample 6) and drinking water from the industrial site (samples 3,4) and Bucharest (sample 7). 
Fig. 1 Map of study area with water sampling sites (sites $l$ to 6) and industrial area which is presumed to be the major source of pollution (sampling site 3 and 4)

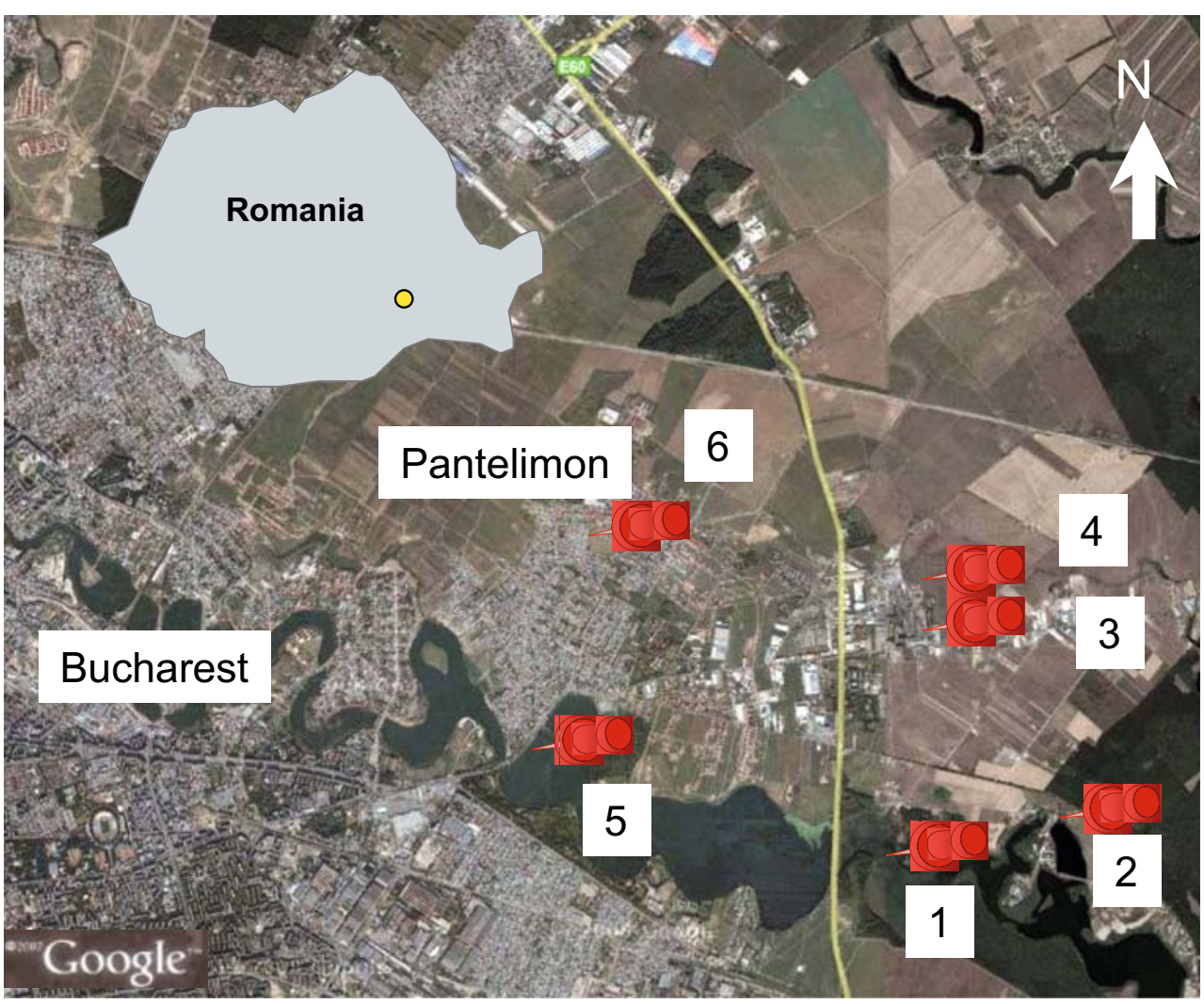

\subsection{Sampling methods}

The soil samples were collected as mixed samples from at least three single samples, dried at $40^{\circ} \mathrm{C}$ and sieved $(<2 \mathrm{~mm})$, extracted by aqua regia and then analyzed by AAS to quantify the total content.

The atmospheric deposition samples were collected with the standardized Bergerhoff apparatus VDI 2119, Blatt 2 (1996), a funnel-bottle-collector as well as a self-constructed collecting pot. The permanently open indicators located on nine different sites around the study site collected atmospheric depositions between August and November 2006 every 2 weeks. The collected samples were extracted by concentrated salpetric acid in a microwave and analyzed by ICP-OES.

Water samples from lakes and Pantelimon were taken just below the surface. The drinking water samples from the industrial site were collected directly from the water network. The water samples were filtered $(<0.45 \mu \mathrm{m})$, acidified with salpetric acid and analyzed by ICP-OES and ICP-MS.

\section{Results}

In the study site, soils were classified according to the World Reference Base (WRB) as chernozem with 2\%-6\% organic matter and cambisol with $2 \%-3 \%$ organic matter (Lacatusu et al. 2000). The $\mathrm{pH}$ is 7 to 8 and the texture is fine to moderate with a high capacity for adsorption.

Around the study site at $0-5 \mathrm{~cm}$ depth, the maximum concentrations of the analyzed heavy metals were approximately $750 \mathrm{mg} / \mathrm{kg} \mathrm{Pb}, 350 \mathrm{mg} / \mathrm{kg} \mathrm{Cu}, 1,300 \mathrm{mg} / \mathrm{kg} \mathrm{Zn}$, and $7 \mathrm{mg} / \mathrm{kg} \mathrm{Cd}$ (Fig. 2) The metal concentrations in soil decrease with increasing distance to the industrial site, except for one location at $1,000 \mathrm{~m}$ in the east.

The maximum heavy metal concentrations in the soil profile were mostly found in deeper soil layers. For lead, approximately $5,000 \mathrm{mg} / \mathrm{kg}$ were found at a soil depth of 10 to $20 \mathrm{~cm}$ at the sampling site $200 \mathrm{~m}$ west from industry (Fig. 3).

The lead concentrations in soil $(0-10 \mathrm{~cm}$ depth) in the closest populated area, Pantelimon town, showed a median value of approximately $150 \mathrm{mg} / \mathrm{kg}$ and a maximum value of $1,300 \mathrm{mg} / \mathrm{kg}$, while the median value of samples from Bucharest $(n=4)$ reached $94 \mathrm{mg} / \mathrm{kg}$ and a maximum value of approximately $200 \mathrm{mg} / \mathrm{kg}$ (Fig. 4).

The highest dust precipitation during the sampling period was found $50 \mathrm{~m}$ east of the industrial site with $138 \mathrm{mg} \mathrm{m}^{-2}$ day $^{-1}$. At the control site in Bucharest, the dust rate, with $23 \mathrm{mg} \mathrm{m}^{-2}$ day $^{-1}$, was much lower and comparable with dust rates at a distance of $1,500 \mathrm{~m}$ from the industrial site. The maximum deposition rates for lead, 
Fig. 2 Heavy metal concentration in soils at $0-2,000 \mathrm{~m}$ distance from the presumably major source of pollution, at $0-5 \mathrm{~cm}$ depth in main wind directions

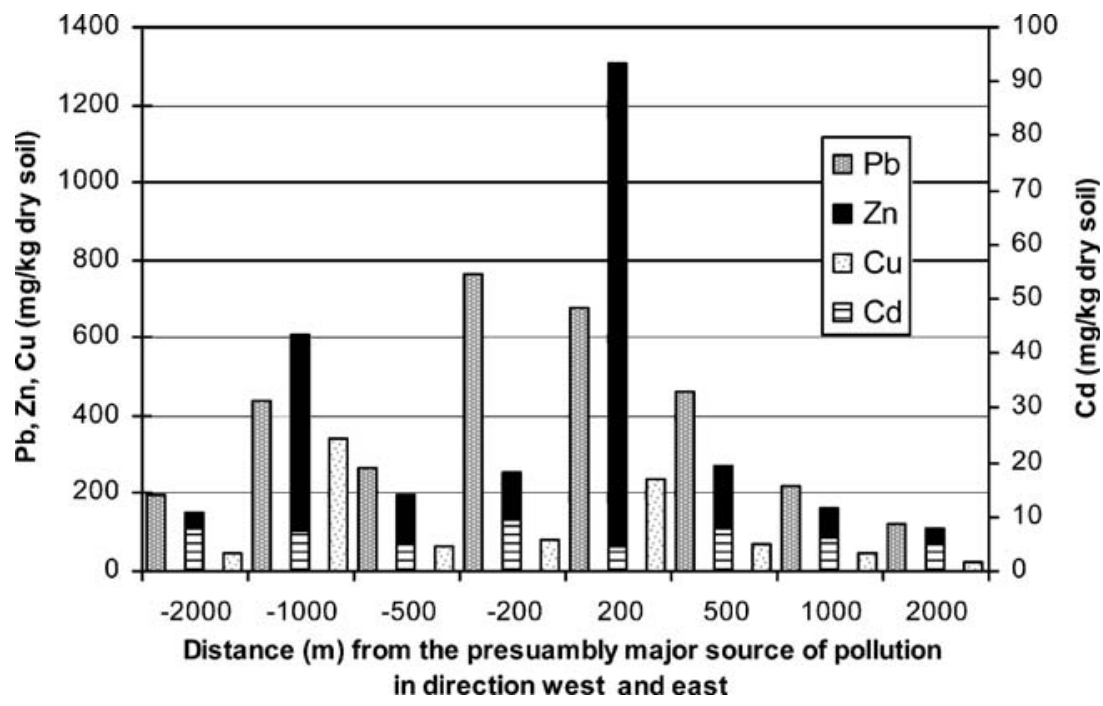

zinc, copper, and cadmium were found $50 \mathrm{~m}$ east of the industrial area with up to 265 times higher deposition rates than found at the control site in Bucharest (Fig. 5).

In all water samples near the industrial site, but also in all control samples from Bucharest, measurable soluble concentrations of heavy metals were found, and the observed $\mathrm{pH}$ was between 7.4 and 8 (Table 1). The maximum concentrations were $0.031 \mathrm{mg} / \mathrm{l} \mathrm{Pb}, 0.49 \mathrm{mg} / \mathrm{l} \mathrm{Zn}$ and $0.083 \mathrm{mg} / \mathrm{l} \mathrm{Cu}$. Soluble lead concentrations were measured in four of seven samples, no lead was found in the control sample of Bucharest.

\section{Discussion}

Increased heavy metal concentrations were found mainly in the study area, but also at the control sites in Bucharest. It is well known that heavy metal contaminations are an environmental risk and, for example, can be toxic for soil microorganisms with severe effects on microbial activity in

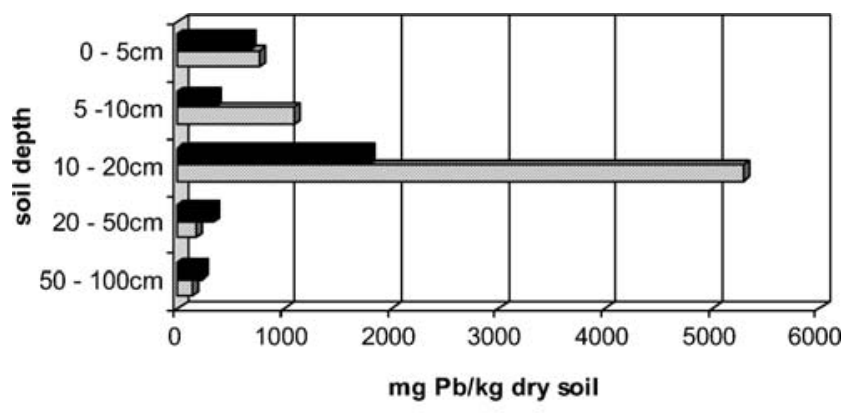

$\square 200 \mathrm{~m}$ west from the presumably major source of pollution - $200 \mathrm{~m}$ east from the presumably major source of pollution

Fig. 3 Lead concentrations in soils at $200 \mathrm{~m}$ distance from the presumably major source of pollution (sampling site 3 and 4 in Fig. 1), in east and west direction, at $0-100 \mathrm{~cm}$ depth these soils (Wang et al. 2007). However, no heavy metal concentrations above action limits for low-concern areas (e. g., $1,000 \mathrm{mg} \mathrm{Pb} / \mathrm{kg}$ dry soil), according to Romanian law, have been observed in the upper $0-5 \mathrm{~cm}$ soil layer, so no direct risk for humans must be expected. The highest lead concentrations were found at a soil depth of $10-20 \mathrm{~cm}$. No clear explanation could be found for this observation. As the measured soil $\mathrm{pH}$ is 7 to 8 , it cannot be expected that heavy metals were mobilized and transferred to deeper soil layers. The land was not ploughed, as it had not been used for agricultural purposes in the last decades. Possibly, bioturbation could have influenced the distribution of the heavy metals in the soil profile on this site.

As expected, there was a trend of decreasing heavy metal concentrations along the sample transect, indicating the industry as an important source for heavy metals in the study area. Similar contamination situations can be observed in other European industrial areas (Sichorova et al. 2004). No agricultural input of heavy metals can be expected in these soils, as the surrounding of the study

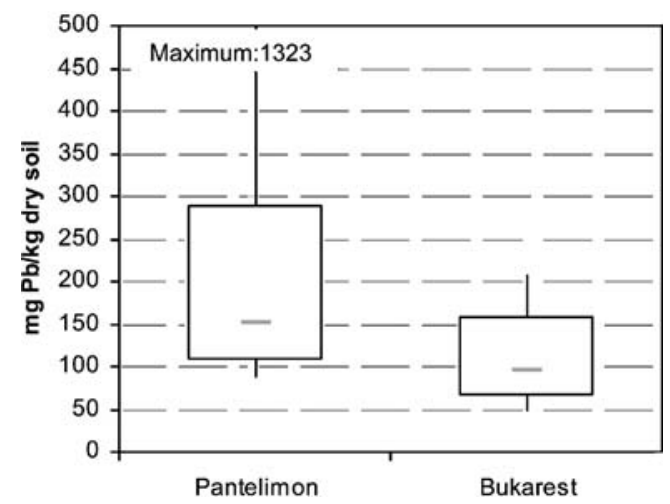

Fig. 4 Box plots of lead concentrations in soil samples in Pantelimon $(n=22)$ and Bucharest $(n=4)$ at $0-10 \mathrm{~cm}$ depth with minimum, maximum, median and quartiles, $25 \%$ and $75 \%$ values 
Fig. 5 Heavy metal concentration in atmospheric depositions at $0-1,500 \mathrm{~m}$ distance from the presumably major source of pollution (sampling site 3 and 4 in Fig. 1) in main wind directions

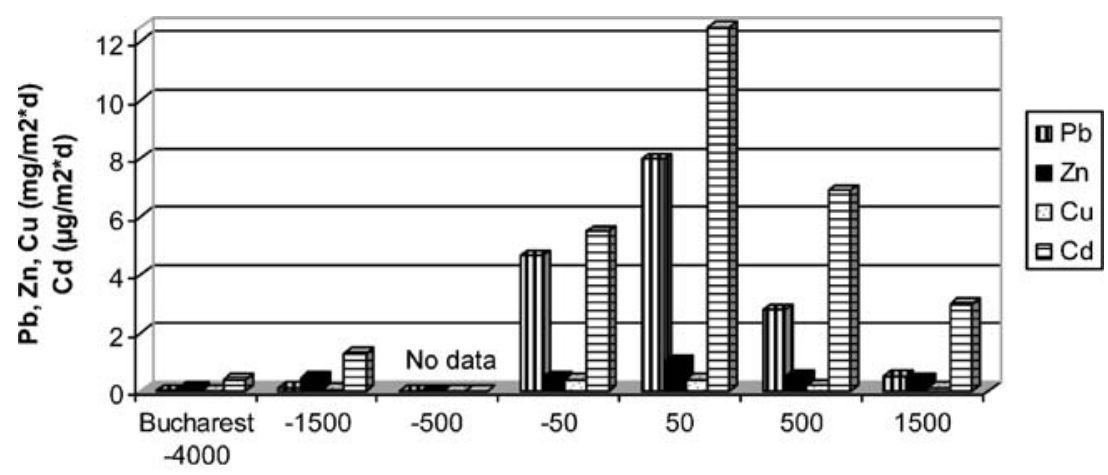

Distance from pollution source $(\mathrm{m})$ in direction west and east and reference site in Bucharest

area is not used for agriculture. The traffic might also be a source for heavy metals, especially for the sampling sites west from the industrial area which are close to a busy road. However, the decreasing heavy metal concentrations along the road with increasing distance to the industry show that traffic is not the primary source for the observed heavy metal contamination. In Bucharest, however, traffic might be the most significant source for heavy metals, especially for lead (Azimi et al. 2005).

In Pantelimon, the median value for lead concentrations was clearly above legal action limits for high-concern areas (100 mg Pb/kg dry soil) according to Romanian law, while the median value was close to this limit in Bucharest. The maximum values in Pantelimon are almost seven times higher than in control samples of Bucharest.

For atmospheric deposition, increased distance to the industrial area resulted in a reduction of dust precipitation and heavy metal concentrations involving such heavy metals as lead (see Fig. 5). The average dust deposition and the heavy metal values around the study area are much higher than at the reference sites in the middle of the city of Bucharest. A simple mass balance calculation for lead in the soil profile $200 \mathrm{~m}$ east of the study area $(0-5 \mathrm{~cm}$, $445 \mathrm{mg} / \mathrm{kg} ; 5-10 \mathrm{~cm}, 348 \mathrm{mg} / \mathrm{kg} ; 10-20 \mathrm{~cm}, 1,790 \mathrm{mg} / \mathrm{kg}$; $20-50 \mathrm{~cm}, 338 \mathrm{mg} / \mathrm{kg} ; 50-100 \mathrm{~cm}, 220 \mathrm{mg} / \mathrm{kg}$; bulk density, $1.3 \mathrm{~g} / \mathrm{cm}^{3}$ ), with the assumption of a relative high background concentration of $30 \mathrm{mg} \mathrm{Pb} / \mathrm{kg}$ and assuming that no lead is discharged from the soil profile, showed, with the actual atmospheric deposition rate of around $5 \mathrm{mg}$
$\mathrm{Pb} / \mathrm{m}^{2} \mathrm{~d}$, that it would last more than 250 years to reach the measured lead loads in this soil. Therefore, we must assume that the atmospheric deposition rates for lead were much higher in the past decades. This would be in good agreement with the fact that the processing of metallic wastes with $\mathrm{Zn}$ and $\mathrm{Cu}$ was stopped in 1989. In 2006, the activities for waste processing were also stopped, with the exception of one installation which has been radically modernized.

Soluble lead concentrations of a fountain and drinking water near the industrial site were above alert limits. In one lake, traces of lead were found, as in the other lakes, and no lead could be measured in the drinking water of Bucharest. It is possible that the high lead emissions of the studied industrial site influence the lead concentrations in water, although the water pipeline system could also be a major source for dispensing lead into the water. The $\mathrm{Zn}$ concentrations in a lake (sample 1) and drinking water near the industrial site (sample 3 ) are approximately 20 times higher than in other samples. Increased $\mathrm{Cu}$ concentrations were found in two lake and one fountain samples. There is no evidence that these contaminations are directly linked to the industrial activity in the study area.

\section{Conclusions}

It was shown that highest metal values in soil and atmospheric deposition are found near the investigated

Table 1 Heavy metal concentrations and $\mathrm{pH}$ in water samples (mg/l)

\begin{tabular}{lllccccc}
\hline Sample & 1 Lake & 2 Lake & 3 Drinking water & 4 Drinking water & 5 Lake & 6 Fountain & 7 Drinking water Bucharest \\
\hline $\mathrm{Pb}$ soluble $(\mathrm{mg} / \mathrm{l})$ & 0.004 & $<0.004$ & 0.09 & 0.027 & $<0.004$ & 0.031 & $<0.004$ \\
$\mathrm{Zn}$ soluble $(\mathrm{mg} / \mathrm{l})$ & 0.49 & 0.016 & 0.28 & 0.019 & 0.018 & 0.013 & 0.035 \\
$\mathrm{Cu}$ soluble $(\mathrm{mg} / \mathrm{l})$ & 0.056 & 0.047 & 0.014 & 0.0017 & 0.0029 & 0.083 & 0.0023 \\
$\mathrm{pH}$ & 7.9 & 7.9 & 7.6 & 8 & 7.7 & 7.8 & 7.4 \\
\hline
\end{tabular}


industrial site rather than at the control sites in Bucharest. This had not necessarily to be expected as other studies found the highest contaminations near the city centre (Mihai et al. 2007). Metal concentrations in soil were found to decrease with increasing distance from the industry. This indicates the influence of the industrial activities on the deposition of heavy metals in the surrounding area. Our results seem to correspond with the fact that the percentage of children from Pantelimon with altered blood concentrations of trace elements is distinctly higher, for most elements, as compared to children in Bucharest (Velea et al. 2008). The lead concentrations in blood of children from Pantelimon are significantly higher than those from Bucharest and were associated with the results of performance tests (Nicolescu et al. 2008).

\section{Recommendations and perspectives}

In areas with exceeded action limits, measures have to been taken as required by law. Detailed risk assessments could help to take necessary actions to protect public health in this area. Furthermore, the cooperation between local authorities and each economic agent will be very useful in the future in order to avoid accidental pollutions. The public should be informed about potential hazards stemming from eating plants grown in that area. Educational programs for schools, informing children about the contamination, should lead to a better understanding of environmental problems and a more sustainable behavior in the future.

Acknowledgment This work was financed by the Swiss National Science Foundation (SNSF), the Swiss Agency for Development and Cooperation (SDC) and the Romanian Ministry for Education and Research (MEC) within the framework of the Swiss-Romanian Cooperation Program on 'Environmental Science and Technology in Romania-ESTROM'. The reported study was performed in the project NEPOLL, focusing on the estimation of the pollution degree of water and soil in the vicinity of the investigated industrial area near Bucharest, Romania.

\section{References}

Azimi S, Rocher V, Muller M, Moilleron R, Thevenot D (2005) Sources, distribution and variability of hydrocarbons and metals in atmospheric deposition in an urban area (Paris, France). Sci Total Environ 337:223-239, Elsevier, www.sciencedirect.com

Kabala C, Singh B (2001) Fractionation and mobility of copper, lead, and zinc in soil profiles in the vicinity of a copper smelter. J Environ Qual 30:485-492

Lacatusu R, Risnoveanu I, Kovacsovics B, Lungu M (2000) The pollution with heavy metals of soils from east part of Bucharest. Soil Sci 34(1):121-134

Martley E, Gulson BL, Pfeiffer HR (2004) Metal concentrations in soils around the copper smelter and surrounding industrial complex of Port Kembla, NSW, Australia. Sci Total Environ 325:113-127

McMartin I, Henderson PJ, Plouffe A, Knight RD (2002) Comparison of $\mathrm{Cu}-\mathrm{Hg}-\mathrm{Ni}-\mathrm{Pb}$ concentrations in soils adjacent to anthropogenic point sources: examples from four Canadian sites. Geochem Explor Environ Anal 2:57-74

Mihai M, Lacatusu I, Murariu A, Meghea A, Stanescu A (2007) Quantification of lead pollution in Bucharest area and potential risks for human health. Environ Eng Manag J 6(5):473-478

Nicolescu R, Petcu C, Cordeanu A, Fabritius K, Schlumpf M, Krebs R, Krämer U, Winneke G (2008) Environmental exposure to lead, but not mercury, aluminum or arsenic, is related to core aspects of the attention deficit hyperactivity disorder (ADHD) in Romanian children: Performance measures and questionnaire data. Environ Health Persp (submitted)

Schulin R, Curchod F, Mondeshka M, Daskalova A, Keller A (2007) Heavy metal contamination along a transect in the vicinity of the iron smelter of Kremikovtzi (Bulgaria). Geoderma 140:52-61

Sichorova K, Tlustos P, Szakova J, Korinek K, Balik J (2004) Horizontal and vertical variability of heavy metals in the soil of a polluted area. Plant Soil Environ 50:525-534

Steinnes E, Lukina N, Nikonov V, Aamlid D, Røyset O (2000) A gradient study of 34 elements in the vicinity of a copper-nickel smelter in the Kola Peninsula. Environ Monit Assess 60:71-88

VDI 2119, Blatt 2 (1996) Messung Messung partikelförmiger Niederschläge, Bestimmung desStaubniederschlags mit Auffanggefässen aus Glas (Bergerhoff-Verfahren) oder Kunststoff. Beuth Verlag GmbH, Berlin

Velea T, Naghi E, Cordeanu A, Petcu C, Schlumpf M, Winneke G, Krebs R (2008) NEPOLL: Environmental pollution in the vicinity of an industrial area near Bucharest and the impact upon the health of people living in this area. Danube News 17:7-9

Wang Y, Shi J, Wang H, Lin Q, Chen Q, Chen Y (2007) The influence of soil heavy metals pollution on soil biomass, enzyme activity, and community composition near a copper smelter. Ecotox Environ Saf 67:75-81 